International Journal of Agriculture, Environment and Bioresearch

Vol. 4, No. 03; 2019

ISSN: $2456-8643$

\title{
FIRST REPORT AND PRELIMINARY EVALUATION OF CASSAVA ROOT NECROSIS IN ANGOLA
}

\author{
Bakelana Zeyimo ${ }^{1,7,8} \uparrow$, Laura M. Boykin ${ }^{5}$, Mahungu Nzola ${ }^{4}$, Mavila Ndofula $^{3}$, Matondo Magole ${ }^{2}$, Nlandu \\ Nduandele $^{3}$, Lunfuankenda Makuati ${ }^{9}$,Tevo Ndomateso ${ }^{1,8}$, Monde Godefroid ${ }^{6,7}$, Justin Pita ${ }^{7}$, Lema ki \\ Munseki $^{8}$ and Tshilenge Kanana ${ }^{1,8}$ \\ ${ }^{1}$ National Institute for Agricultural Research Studies (INERA), DR. Congo. \\ ${ }^{2}$ Ministerio da Agricultura, Angola. \\ ${ }^{3}$ Instituto de Desevolvimento Agrario (IDA), Angola. \\ ${ }^{4}$ International Institute of Tropical Agriculture (IITA) \\ ${ }^{5}$ School of Molecular Sciences and Australian Research Council Centre of Excellence in Plant Energy \\ Biology,University of Western Australia, Crawley, Perth, WA 6009 Australia \\ ${ }^{6}$ Institute Faculty of Agricultural Sciences / Yangambi, DR. Congo \\ ${ }^{7}$ West African Virus Epidemiology / WAVE, Abidjan, Ivory-Coast. \\ ${ }^{8}$ Agriculture Faculty - Kinshasa University / DR.Congo \\ ${ }^{9}$ AVODECOM, Associacao dos Voluntarios para o Desenvolvimento Communitario Integrado, Angola.
}

http://doi.org/10.35410/IJAEB.2019.3746

\begin{abstract}
Cassava is a main staple food for 800 million people world-wide. Production is limited by pest and pathogens. The most devastating cassava viruses are Cassava Brown Streak Virus and Uganda Cassava Brown Streak Virus- both causing severe root necrosis called Cassava Brown Streak Disease. In the last 10 years, the Cassava Brown Streak Disease (CBSD)has spread across Africa from the east coast of Africa to central Africa. Similar root necrosis to cassava brown streak disease has also been identified in the Democratic Republic of Congo where the first symptoms were identified in 2002 in Kinshasa and Kongo central province. In 2012, the presence of CBSD was confirmed in eastern Democratic Republic of Congo. All attempts since 2002 in western Democratic Republic of Congo to identify the cause of these root necrosis have failed. In 2017, a team of scientists surveying the Songololo Territory in the Kongo central province at the northern Angola, identified the same root necrosis similar to CBSD in several localities bordering Angola. These unexpected results will foreshadow the presence of cassava root necrosis in Angola. This preliminary investigation in northern Angola was conducted specifically in the Zaire province and the territory of Mbanza Kongo at approximatively $62 \mathrm{kms}$ from the Democratic Republic of Congo border in order to verify, whether or not, these root necrosis are present in Angola. Results obtained from this exploratory survey in several fields of the Zaire province and territory of Mbanza Kongo confirmed, for the first time, the presence of cassava root necrosis in Angola, similar to CBSD, as identified in western DRC
\end{abstract}

Keywords: Cassava Brown Streak Disease - Root necrosis - Incidence - Severity - AngolaDemocratic Republic of Congo. 


\section{INTRODUCTION}

Cassava is one of the most important food staple crops in many countries of sub-Saharan Africa. Human population growth rates of many of these countries of this sub-region continue to be some of the highest in the world, and consequently there is an urgent need to match this growth with concomitant increases in food production.

Cassava production in Africa is restricted by a diverse set of constraints [1]. Arguably the most economically important, however, are the two virus diseases : Cassava Mosaic Disease (CMD) and Cassava Brown Streak Disease (CBSD). Both have been recognized for many decades, but have become increasingly damaging in recent years [1].

CMD is caused by viruses of the family Geminiviridae : genus Begomovirus ([2], [3])

CBSD was first reported in the early 1930s from the coastal zone of Tanzania, in East Africa [4], the same region in which the earliest observations of CMD had been made [5]. For the remainder of the 20th century, the distribution of CBSD was largely confined to lowland coastal areas of Kenya, Tanzania and Malawi ([6], [7],[8]). Unlike CMD, which only expresses symptoms in the leaves of cassava, CBSD's most economically significant symptom is a dry brown-black necrotic rot of the tuberous root [7]..

Other important symptoms include yellow blotchy chlorosis in the secondary and tertiary leaf veins, as well as brown necrotic streaks on the green portions of stems and seed capsules. Leaf symptoms are most prominent on the lower parts of the plant, which can make them hard to recognize unless plants are examined carefully and before leaves have senesced. All of these leaf, stem and root symptom types may occur in severely affected plants. More commonly, however, infected plants will have only one or two symptom types [9]..

Since the main source of yield loss to CBSD is presumed to be root rot, germplasm improvement efforts have focused mainly on selecting varieties that do not show root necrosis, or express symptoms at a late stage of growth. These varieties are typically referred as "tolerant".

Two distinct but similar virus species are now recognized: Cassava brown streak virus (CBSV) and Ugandan cassava brown streak virus (UCBSV). These are referred to collectively as Cassava Brown Streak Virus (CBSVs). Both are in the family Potyviridea, genus Ipomovirus.

CBSVs, like the CMGs, have been shown to be transmitted by the whitefly vector, Bemisia tabaci (Gennadius) [10] and recently it has been suggested that CBSV might be transmitted by aphids [11]. Both are disseminated readily through cuttings taken inadvertently from infected parent material.

Prior to 2014, CBSD was considered to be limited in its distribution to areas below 1,000 m above sea level (m.a.s.l) ([12],[7]) northwestern Tanzania [8], and southern Uganda [13] - all locations significantly above 1,000 m.a.s.l. Since, 2014, CBSD has spread throughout the Great Lakes region of East and Central Africa, driven by unusually abundant populations of the whitefly vector [9].. 
The virus has been confined to the east coast of Africa but over the last decade it has begun to spread rapidly across the continent from east to west [14].

CBSD is now one of the leading causes of cassava losses in East Africa and its ongoing spread threatens the major cassava - growing areas of central and west Africa [15].

In 2003, scientists from INERA and IITA reported for the first time similar root symptoms to cassava brown streak disease in Democratic Republic of Congo (DRC) and more precisely in the provinces of Kinshasa (Plateau des Batékés) and Kongo Central [16].

In 2012, [17] confirmed at the molecular level the presence of cassava brown streak disease in eastern DRC, precisely the UCBSD (Ugandan Cassava Brown Streak Disease) strain.

But up to date, all PCR tests did not detect any causative agent related to the observed CBSDlike symptoms in western DRC and the disease was still referred as "CBSD-like disease" [18].

Since it has been confirmed by NGS (Next Generation Sequencing) that no virus is present in leaves samples from diseased plants of CBSD-like symptoms and the disease could no-longer be referred as similar to CBSD and the disease has been called "Cassava Root Necrosis Disease" (CRND) (Bakelana et al., unpublished).

In 2017, a team of INERA - Mvuazi researchers surveying the northern zone of Angola in DRC (Lufu and Kuzi area in the Songololo Territory in the Kongo central province) under the WAVE project (Western Africa Virus Epidemiology), identified for the first time, the same root necrosis similar to CBSD.

These unexpected results of root necrosis lead to the current study and exploration of cassava in northern Angola. No studies to date have reported the presence of root necrosis in Angola. It is in this context that an exploratory survey was initiated under the WAVE program to search for cassava root necrosis in the province of Zaire in northern Angola, which is along the DRC border.

\section{MATERIALS AND METHODS.}

The exploratory survey was conducted in the province of Zaire and in the territory of Mbanza Kongo. Eleven (11) villages were surveyed from 01 to 05 October 2017. Names of villages are as follow: Diadia Kuimba, Kuimba, Sede Kuimba, Kuzi, Tanda Kuzi, Kinkuvila, Buela Songamani, Ngandu, Ngozela, Kienga Luvo and Luvo Lula.

Materials used during this survey consisted of a motorcycle, a GARMIN Etrex 20 GPS, a digital camera, a machete, a questionnaire for interviewing farmers, a sound recorder, data sheets for data collection, and illustrated images of brown streak root necrosis symptoms. The methodology used consisted of questioning farmers and recording data on maximum severity of root necrosis using a specific scale. The incidence of root necrosis was deduced from data collected on maximum root severity. The sample of our study consisted of 11 villages selected randomly from a list of 42 villages constituting the territory of Mbanza Kongo. 
The survey was conducted in two phases: farmers interviews and field observations. In order to learn about the situation of root necrosis on the ground, we started the survey by talking with farmers of different villages, through a pre-established questionnaire and presented to them, printed photos of CBSD root symptoms. Interviews were based on key issues related to cultivated varieties, their origins, the year of symptom appearance in the site and types of symptoms observed. Regarding field observations, data on maximum severity of root necrosis were recorded from various fields which were randomly selected in each village. The same number of fields were selected per village.

Only the underground part of the plant (roots) were taken into account during the survey because observations made from western DRC never showed any relation between root necrosis symptoms with any leaf symptoms. For the assessment of root necrosis (Figure 1), sampled plants were uprooted. Roots were counted, and each root was then cut cross-sectionally five times at regular intervals along the length of the root. A symptom score was then recorded for each cut, using the 1 - to - 5 scoring of Hillocks and Thresh (2000) (see table 1 in Annex). The root necrosis severity was assessed on each of the five sections, as follows:

- Apparently healthy root;

-Less than $5 \%$ of necrosis;

-Corresponds to $5-12 \%$ of necrosis;

- Corresponds to $12-30 \%$ of necrosis

-Corresponding to more than $30 \%$ of root necrosis.

The maximum root necrosis severity was recorded for each plant and the incidence was deduced from data on severity root necrosis and then calculated as follow:

Incidence $=($ number of diseased plants $) /$ (number of plants observed $) \times 100$.
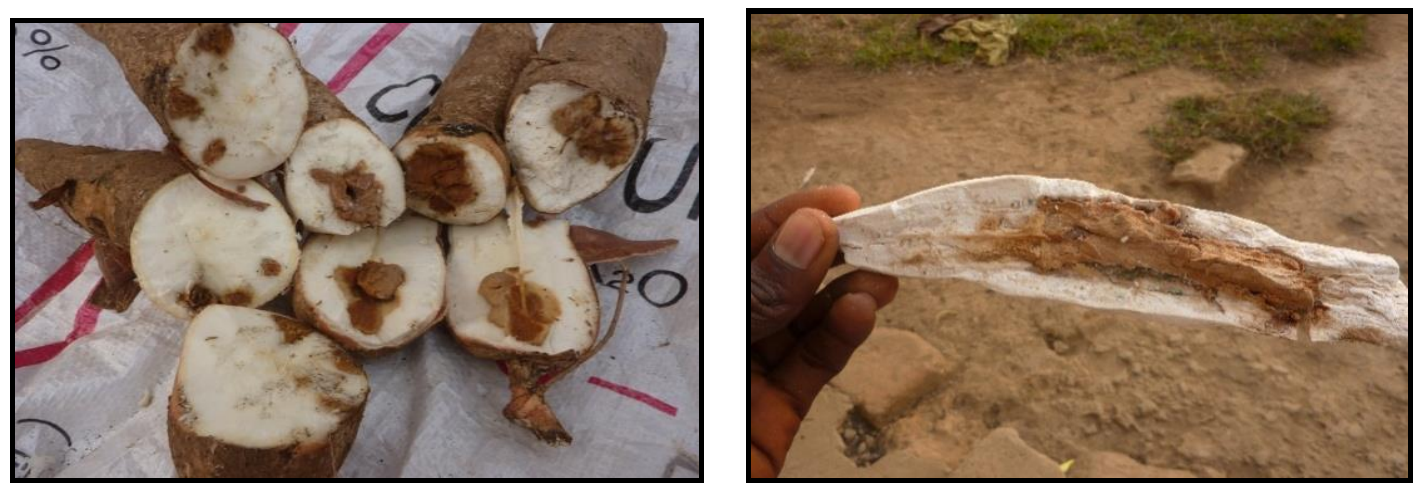

Figure 1. Typical CBSD-like root necrosis as observed in northern Angola (in fresh and dry roots)

\section{RESULTS AND DISCUSSION}


Data from questionnaires and forms were recorded in an Excel file in order to facilitate their statistical analysis using the Statistix 8.0 software. Observations, comments and different interpretations made from results obtained are presented below.

Data analysis revealed that most farmers confirmed the observation for several years ago of cassava root necrosis, which are locally known as "muanzi a sonia " which means " imperata wounds " because farmers are believing that these necrosis are due to wounds caused on cassava roots by the weed known as Imperata cylindrica.

Leaves and stem assessments: Typical CBSD leaves and stems symptoms were not found in northern Angola as in western DRC and Congo Republic [19].

Root rot assessment: Some cases of root rot where encountered on severe damaged plants

\section{Maximum severity and incidence of root necrosis in relation to varieties:}

Observations made in western DRC and Congo republic showed that varieties represent the main factor for the spreading of root necrosis symptoms through any area as well as the varietal genetic difference has been confirmed in DRC and in Congo Republic [19]. Even though resistant varieties do not yet exist, tolerant varieties are more preferred by farmers because they show symptoms or root necrosis, late during their growing cycle. The RAV variety is one of the most cultivated variety in Mfouati District in the Congo republic and known as Ya leger [19]. In Kongo central province in DRC, RAV is also considered as one of the most cultivated and susceptible variety. Data collected in northern Angola in relation to the varietal prevalence in different cassava fields visited during the exploratory survey are presented in table 1 below.

Table 1: Prevalence of cassava varieties in relation to surveyed localities.

\begin{tabular}{|l|l|l|}
\hline $\mathbf{N}^{\circ}$ & Location & $\begin{array}{l}\text { Predominant } \\
\text { variety }\end{array}$ \\
\hline $\mathbf{1}$ & Diadia Kuimba & Santos \\
\hline $\mathbf{2}$ & Kuimba & Santos \\
\hline $\mathbf{3}$ & Sede Kuimba & RAV \\
\hline $\mathbf{4}$ & Kuzi & RAV \\
\hline $\mathbf{5}$ & Tandakuzi & RAV \\
\hline $\mathbf{6}$ & Kinkuvila & Guzu \\
\hline $\mathbf{7}$ & BuelaSongamani & Kisidi \\
\hline $\mathbf{8}$ & Ngandu & RAV \\
\hline $\mathbf{9}$ & Ngozela & RAV \\
\hline $\mathbf{1 0}$ & KiengaLuvo & Mpesukidi \\
\hline $\mathbf{1 1}$ & Luvo Lula & Kingela \\
\hline
\end{tabular}

Results presented in table 1 show that the RAV variety seems to be the most cultivated (45.45\%) in the province of Zaire in northern Angola. Others cassava varieties (landraces and improved) 
encountered in cassava fields also showed to be susceptible to root necrosis, with maximum severity levels varying between 4 and 5. Data collected on maximum severity and incidence of the disease in different sites are shown in figure 2 below.

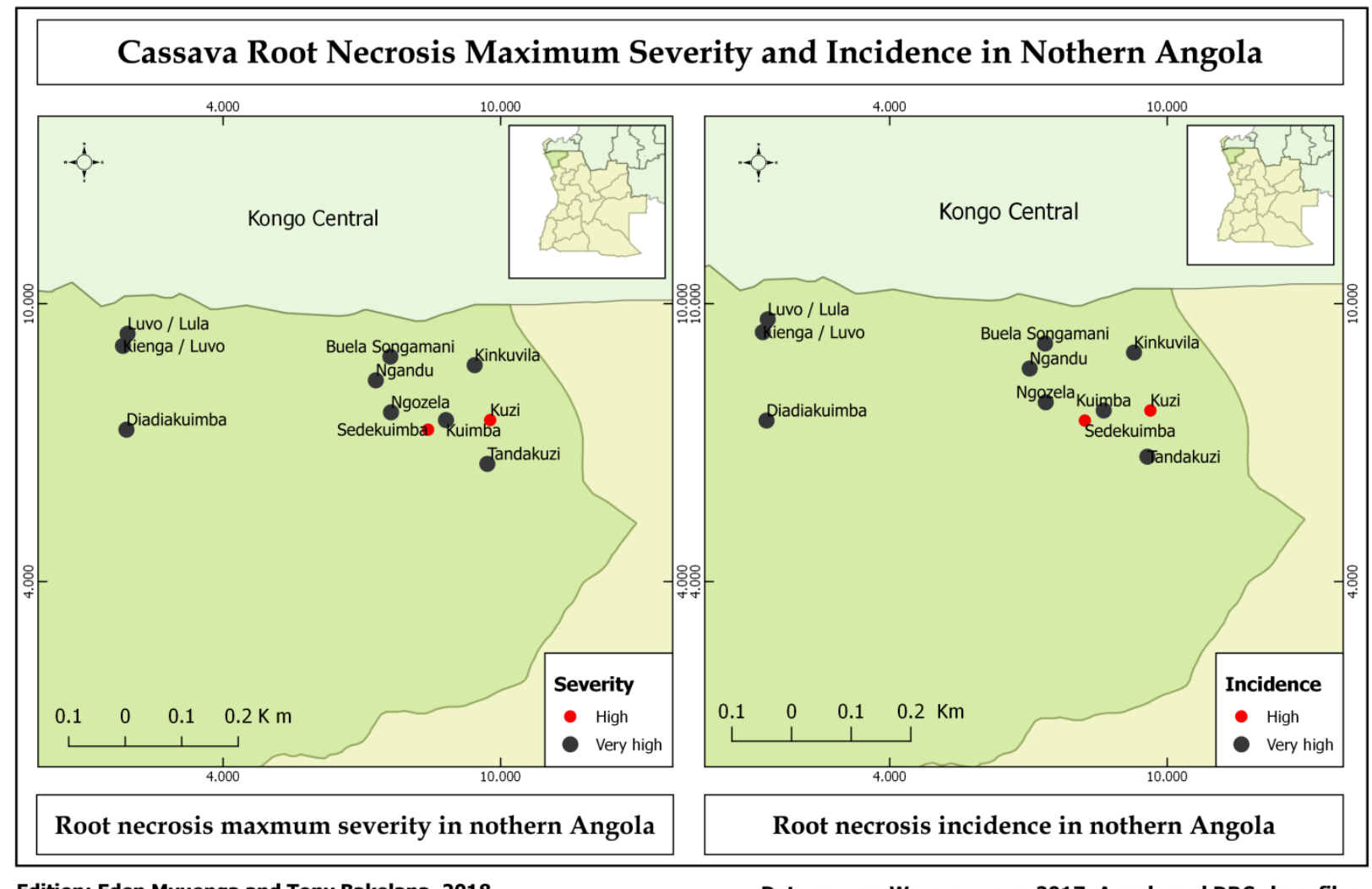

Edition: Eden Mvuenga and Tony Bakelana, 2018

Data source: Wave surveys, 2017; Angola and DRC shapefiles Datum: WGS 84

Fig. 2. Maximum severity and incidence of cassava root necrosis in northern Angola.

Results reported in figure 2 show that the maximum severity level is high across all visited localities. This represents a very high level of risk and high sensitivity level for cassava varieties in cultivation in this area. These results are in line with results recorded in areas of high disease infestation in western DRC and in Congo Republic. These results confirm the high prevalence of the root necrosis disease along the DRC border area of Kongo central province close to Angola, with the village of Lukuakua as one of the hotspot of the disease in Kongo central province as well in western DRC.

\section{CONCLUSION}

The exploratory investigation that was conducted in northern Angola specifically in the province of Zaire and the Territory of Mbanza Kongo, showed the following: 
प- CBSD-like root necrosis do exist in Angola and are sometimes confused with cassava root wounds caused by Imperata cylindrica. This constitutes a poor farmer perception considering the severity and the incidence levels of the disease with regard of the Imperata cylindrica distribution which is not present in all cassava fields while root necrosis were found in almost all cassava fields.

$\square$ - Cassava genetic variability has been confirmed in terms of tolerance to the disease. Varieties RAV, Mvuama, Sadisa, Butamu, TME 419 and Precoce d'Angola appear to be very susceptible unlike landraces Tona, Kinkadinkadi and Mawete. We should note that all improved varieties in our investigation area were introduced from DRC.

$\square$ - The maximum disease severity level ranging between 4 and 5, combined with a high incidence of the disease, represents a real threat of the disease for cassava cultivation in the region.

We suggest that research and awareness work be put in place and future plans for research work in Angola can be summarized as follow:

1. Conduct an in-depth study in the same district to assess the current status of the disease by assessing variety yields and losses due to the disease;

2. Carry out similar investigations across the country;

3. Research needs to be conducted to allow the development of new resistant varieties.

4. Need of Next Generation studies in order to identify pathogens that are causing root necrosis in the territory of Mbanza Kongo with the option of using on ground for direct sequencing the real-time portable DNA sequencer that has been deployed in Tanzania, Uganda and Kenya to quickly identify plant viruses [20].

5. Since the disease is likely not present in all areas of the country, quarantine may be of use and could be the first step in tackling the disease in Angola. The next step could be to identify high yielding resistant cultivars to root necrosis and others majors diseases and pests.

6. Once resistant cultivars have been identified, they should be multiplied and distributed to farmers.

7. There should be a need to organize campaigns and trainings for farmers as well as extension staff in field disease identification and application of control measures.

\section{ACKNOWLEDGEMENTS}

This piece of work was carried out by the National Cassava program of INERA under the technical support of the WAVE program. We are grateful to the WAVE program for the technical and financial support provided to western and central African countries. We would like to thank exceptionally Mr. MavilaNdofula, a collaborator of Instituto de Desevolvimento Agrario (IDA), for his willingness for collecting data on ground. 
Our gratitude goes also to Mrs. Matondo Magole and Nlandu Nduandele, from the Ministerio da Agricultura and the Instituto de Desevolvimento Agrario (IDA), who facilitate data collection during the survey.

We cannot forget farmers who received surveyors in their field and agreed to uproot cassava plants, free of charge, to facilitate root necrosis observations.

\section{REFERENCES.}

[1] J.P. Legg, S.C. Jeremiah, HM Obiero, M.N. Maruthi, I. Ndyetabula, G. Okao-Okuja, "Comparing the regional epidemiology of the cassava mosaic and cassava brown streak virus pandemics in Africa". Virus Res. 159: 161-170, 2011.

[2] K.R. Bock, R.D. Roods," The etiology of African Cassava mosaic disease". Plant Dis.67, 994-995, 1983

[3] Y.G. Hong, D.J. Robinson, B.D. Harrison, "Nucleotide sequence evidence for the occurence of three distinct whitefly-transmitted geminivirus in cassava". J.Gen.Virol.74.2437-2443, 1993.

[4] H.H. Storey, "Virus diseases of East African plants. VI-A progress report on studies of the disease of cassava", East Afr. Agric. J.2. 34-39, 1936.

[5] O. Warburg, "Die kulturpflanzenusambaras". Mitt. Deutsch. Schutz. 7. 131, 1984.

[6] R.J. Hillocks, M.D. Raya, J.M. Thresh, "Factors affecting the distribution, spread and symptom expression of cassava brown streak disease in Tanzania", Afr. J. Root Tuber Crops 3. 57-61, 1999.

[7] R.F.J. Nichols, 1950, "The brown streak disease of cassava: distribution, climatic effects and diagnostic symptoms", East Afr. Agric. J.15. 154-160, 1950.

[8] J.P. Legg, M. Raya, "Survey of cassava virus diseases in Tanzania", Int. J. Pest : Manage.44(1). 17-23, 1998.

[9] J.P. Legg, S.C. Jeremiah, H.M. Obiero, M.N. Maruthi, I. Ndyetabula, G. Okao-Okuja, H. Bouwmeester, S. Bigirimana, W. Tata-Hangy, G. Gashaka, G. Mkamilo, T., Alicai, P. Lava Kumar, "Comparing the regional epidemiology of the cassava mosaic and cassava brown streak virus pandemics in Africa". Virus Research 159 . 161-170, 2011.

[10] M.N. Maruthi, R.J. Hillocks, K. Mtunda, M.D. Raya, M. Muhanna, H. Kiozia, "Transmission of Cassava brown streak virus by Bemisia tabaci (Gennadius)", J. Phytopathol.153: 307-312, 2005.

[11] E. Ateka, T. Alicai, J. Ndunguru, F. Tairo, P. Sseruwagi, S. Kiarie et al. , "Unusual occurrence of a DAG motif in the Ipomovirus Cassava brown streak virus and implications for its vector transmission", PLoS ONE 12(11): 2017. https://doi.org/10.1371/journal.pone.0187883

[12] R.J. Hillocks, M. Raya and J.M.Thresh, "The association between root necrosis and aboveground symptoms of brown streak virus infection of cassava in southern Tanzania". Integrated Pest Management Reviews 2, 125-138, 1996.

[13] R.J. Hillocks and D.L. Jennings, "Cassava Brown Streak Disease, a review of present knowledge and research needs", Int. J. Pest Man; 49:225-234, 2003.

[14]I.L. Ndyetabula, S.M. Merumba, S.C. Jeremiah, S. Kasele, GS. Kamilo, F.M. Kagimbo and J.P. Legg, "Analysis of interactions between cassava brown streak disease symptom types 
facilitates the determination of varietal responses and yield losses, Plant Disease, 100(7), 13881396, 2016.

[15] J.P. Legg, P. Sseruwagi, R. Shirima, S.Bigirimana, G. Gashaka, W. Hans-Herrmann, S. Jeremiah, H. Obiero, I. Ndyetabula, W. Tata-Hangy, C. Masembe, J. Brown, "Spatio-temporal patterns of genetic change amongst populations of cassava Bemisia tabaci whiteflies driving virus pandemics in East and Central Africa", irus Research

Volume 186, 24 June 2014, Pages 61-75, 2017.

[16] N.M. Mahungu, M. Bidiaka, W. Tata, S. Lukombo and S. N'luta, "Cassava brown streak disease-like symptoms in Democratic Republic of Congo". ROOTS; 8: 8-9, 2003.

[17] W. Mulimbi, X. Phemba, B. Assumani, P. Kasereka, S. Muyisa, H. Ugentho, R. Reeder, JP. Legg, L. Laurenson, R. Weekes, F.E.F. Thom, "First report of Ugandan cassava brown streak virus on cassava in Democratic Republic of Congo" ,New Dis. Rep. 26, 11, 2012. http://dx.doi.org/10.5197/j.2044-0588.2012.026.011

[18] Z. Bakelana, E. Magembe, L. Boykin, M. Macharia, N. Mahungu, T. Hangy, D. Lutete, G. Monde, J. Harvey, J. Ndunguru, C. Kayuki, J. Pita, K.M. Lema, K. Tshilenge, "Attempts to Identify Cassava Brown Streak Virus in Western Democratic Republic of Congo," Journal of Agriculture Science, Vol. 11. ㅇ2, 2019.

[19] Z. Bakelana, Z. Musben, L. Boykin, J. Pita, A. Mvila, G. Monde, M.N. Mahungu, Mpika, K.M. Lema, K. Tshilenge, "First report and preliminary evaluations of cassava brown streaklike root necrosis in Congo Republic", International Journal of Development Research (08), 22400-22407, 2018.

[20] L. Boykin, A. Ghalab et al. "Real time portable genome sequencing for global food security" [version 1; referees: 1 approved, 1 approved with reservations]. F1000Research 2018, 7:1101 (https://doi.org/10.12688/f1000research.15507.1) 
International Journal of Agriculture, Environment and Bioresearch

Vol. 4, No. 03; 2019

ISSN: $2456-8643$

Table 1: Description of visual diagnostic scale of CBSD

\begin{tabular}{|c|c|c|c|c|}
\hline $\begin{array}{l}\text { Disease } \\
\text { parameter }\end{array}$ & $\begin{array}{l}\text { Plant } \\
\text { part } \\
\text { assessed }\end{array}$ & $\begin{array}{l}\text { symptomatic } \\
\text { /damaged }\end{array}$ & $\begin{array}{l}\text { Score } \\
\text { scale }\end{array}$ & Description \\
\hline \multirow[t]{15}{*}{ severity } & Foliar & $0 \%$ & 1 & $\begin{array}{l}\text { None of the leaves has chlorosis } \\
\text { characteristic for CBSD }\end{array}$ \\
\hline & & $1-5 \%$ & 2 & $\begin{array}{l}\text { Slight chlorotic spots characteristic of } \\
\text { CBSD seen on leaves }\end{array}$ \\
\hline & & $5-12 \%$ & 3 & $\begin{array}{l}\text { CBSD chlorotic spots/blotches easily } \\
\text { observable on leaves }\end{array}$ \\
\hline & & $12-30 \%$ & 4 & $\begin{array}{lll}\text { Appreciable CBSD } & \text { chlorotic } \\
\text { spots/blotches seen on leaves } & \end{array}$ \\
\hline & & $30-100 \%$ & 5 & $\begin{array}{l}\text { Very severe chlorotic/necrotic blotches } \\
\text { and leaf wilt }\end{array}$ \\
\hline & Stem & $0 \%$ & 1 & No necrotic spot or lesion is seen on stem \\
\hline & & $1-5 \%$ & 2 & $\begin{array}{l}\text { Slight chlorotic spots on tender portion of } \\
\text { the stem }\end{array}$ \\
\hline & & $5-12 \%$ & 3 & $\begin{array}{l}\text { Necrotic spots are numerous, coalesced to } \\
\text { small lesions }\end{array}$ \\
\hline & & $12-30 \%$ & 4 & $\begin{array}{l}\text { Severe necrotic lesions enlarged into } \\
\text { streaks }\end{array}$ \\
\hline & & $30-100 \%$ & 5 & $\begin{array}{l}\text { Severe necrotic lesions, streaks, withering } \\
\text { and die-back }\end{array}$ \\
\hline & Root & $0 \%$ & 1 & $\begin{array}{l}\text { None of the roots has necrosis } \\
\text { characteristic for CBSD }\end{array}$ \\
\hline & & $1-5 \%$ & 2 & Small portion of roots bears necrotic spots \\
\hline & & $5-12 \%$ & 3 & $\begin{array}{l}\text { Appreciable proportion of the roots is } \\
\text { obviously necrotic }\end{array}$ \\
\hline & & $12-30 \%$ & 4 & $\begin{array}{l}\text { Roots mostly necrotic, not suitable for } \\
\text { consumption }\end{array}$ \\
\hline & & $30-100 \%$ & 5 & Roots are almost/totally necrotic, started \\
\hline
\end{tabular}

